Volume 10 Nomor 2, April 2019, p.098-106.

Faculty of Law, Universitas Kristen Maranatha

ISSN: 2085-9945 I e-ISSN: 2579-3520

Nationally Accredited Journal by SINTA

\title{
Implementasi Gadai Syariah (Rahn) Untuk Menunjang Perekonomian Masyarakat di Indonesia
}

\section{Pamonaran Manahaar}

Faculty of Law, Padjajaran University

pamonaran@gmail.com

Submitted: 2018-12-21 ;Reviewed: 2019-04-10; Accepted: 2019-04-30

\begin{abstract}
The development of the economy and business world is always followed by the development of the need for business capital and additional facilities for business capital needed to accommodate the needs needed for the development and development of modern society. ) In Indonesia and the benefits of Sharia Pawn (Ranh) compared to other Institutions to Support the Community Economy. This research was conducted by normative juridical method. The primary legal material is a regulation and legal analysis with steps of deductive reasoning. In conclusion, the implementation of Indonesian Islamic pawnshop has been very developed in line with the times and the rise of financial institutions in accordance with the practice of sharia began to be carried out. This Islamic sharia practice or what is called rahn is very brave, there is no imposition of usury or interest on loans given. Besides that sharia provision is very beneficial for the community, judging from its benefits, Islamic mortgage is a solution for the community in helping to increase the occurrence of various activities needed, which in essence is in the mortgage to help the community.
\end{abstract}

Keywords: Business capital; ranh; society

\section{PENDAHULUAN}

Perkembangan perekonomian dan dunia bisnis selalu diikuti oleh perkembangan kebutuhan akan modal usaha dan pemberian fasilitas tambahan modal usaha yang selalu memerlukan jaminan dimana hal ini dilakukan demi keamanan pemberian penambahan modal tersebut dalam arti piutang yang terjamin dengan adanya jaminan, Inilah yang mendasari pentingnya lembaga jaminan. Bentuk lembaga jaminan, sebagian besar mempunyai ciri-ciri internasional yang dikenal hampir di semua negara dan perundangundangan modern, yaitu bersifat menunjang perkembangan ekonomi dan perkreditan serta memenuhi kebutuhan masyarakat akan fasilitas modal. 
Lembaga jaminan berperan penting dalam pengembangan dan pertumbuhan masyarakat industri modern. Produksi berskala besar dengan kebutuhan investasi yang membutuhkan modal yang besar tidak mungkin dipenuhi tanpa bantuan para pengusaha untuk mendapatkan tambahan modalnya melalui mekanisme kredit dan menjadi tumpuan investasi mekanisme saving.

Mengutip dari pendapat Bung Hatta, yang menyatakan bahwa perjuangan masyarakat dalam memenuhi kebutuhan hidup, tidak lain semata-mata untuk menuju tingkat kemakmuran (kesejahteraan) yang diharapkan, yang barang tentu secara jelas untuk mencapainya terdapat berbagai masalah serta hambatan yang harus dihadapi. Untuk itu, pemerintah dalam hal ini, dengan amanat UUD yang diemban dan selaku pihak yang paling bertanggung jawab terhadap kesejahteraan masyarakat dituntut untuk berusaha menciptakan kemakmuran di masyarakat dengan menempuh berbagai cara, yang diantaranya dengan meminta lembaga keuangan untuk berperan aktif dalam membantu perkembangan ekonomi masyarakat. Terasa janggal kiranya jika peningkatan pertumbuhan ekonomi masyarakat tersebut, tidak dihubungkan dengan peningkatan dan upaya memenuhi kebutuhan pada sektor rumah tangga sebagai salah satu elemen dasar dari terbentuknya masyarakat yang berkemakmuran. ${ }^{1}$

Dalam realitas sosial ekonomi masyarakat kerap dikemukakan kondisi masyarakat yang memiliki harta dalam bentuk selain uang tunai dan pada saat yang bersamaan yang bersangkutan mengalami kesulitan likuiditas hingga membutuhkan dana dalam bentuk tunai. Pilihan transaksi yang sering digunakan oleh masyarakat dalam menghadapi masalah ini adalah menggadaikan barang-barang yang berharga. Tugas pokok dari lembaga pegadaian syariah adalah memberikan pinjaman kepada masyarakat yang membutuhkan. Pemberian pinjaman ini tidak terbatas untuk kalangan atau kelompok masyarakat tertentu, namun di Indonesia pemanfaat lembaga keuangan ini masih didominasi oleh kalangan menengah ke atas, dan masih sedikit menjangkau kalangan menengah ke bawah. Dalam upaya mengubah persepsi masyarakat, salah satu cara yang digunakan lembaga gadai adalah dengan menciptakan motto "menyelesaikan masalah tanpa masalah". Dengan motto tersebut diharapkan masyarakat tidak lagi segan atau ragu untuk datang ke pegadaian. Di Indonesia saat ini, ada dua tipe lembaga gadai yaitu pegadaian konvensional dan pegadaian syariah. Menurut Rais (2005), implementasi operasi pegadaian syariah pada dasarnya hampir sama dengan pegadaian konvensional. Namun yang membedakan adalah pegadaian konvensional menerapkan sistem riba atau meminta biaya tambahan atas dana yang dipinjamkan, yang mana hal ini tidak ada pada pegadaian syariah. ${ }^{2}$ Dalam pegadaian syariah yang diutamakan adalah dapat memberikan kemaslahatan sesuai dengan yang diharapkan masyarakat, dengan tetap menjauhkan praktek riba, qimar (spekulasi), maupun qharar (ketidak pastian), sehingga

\footnotetext{
${ }^{1}$ Prihantono, "Peran Bank Dan Pegadaian Syariah Dalam Pemenuhan Kebutuhan Ekonomi Rumah Tangga”, Jurnal Khatulistiwa - Journal Of Islamic Studies, Volume 4 Nomor 1 Maret 2014, hlm. 64.

${ }^{2}$ Rachmad Saleh Nasution, "Sistem Operasional Pegadaian Syariah Berdasarkan Surah Al-Baqarah 283 pada PT. Pegadaian (Persero) Cabang Syariah Gunung Sari Balikpapan”, Al-Tijary Jurnal Ekonomi dan Bisnis Islam, 2016, Vol. 1, No. 2, hlm. 94.
} 
tidak berimplikasi pada terjadinya ketidakadilan dan kedzaliman pada masyarakat dan nasabah. ${ }^{3}$ Gadai termasuk salah satu tipe perjanjian hutang-piutang. Untuk menjamin adanya unsur kepercayaan dari pihak kreditur terhadap pihak debitur, maka diperlukannya ada barang yang digadaikan sebagai jaminan terhadap hutang atau pinjaman tersebut. Barang tersebut tetap merupakan milik dari orang yang menggadaikan, namun dikuasai oleh penerima barang.

Berdasarkan latar belakang diatas, penulis akan mengakaji Implementasi Gadai Syariah (Rahn) Di Indonesia dan apa keuntungan Gadai Syariah (Ranh) dibandingkan dengan Lembaga pembiayaan lain Untuk Menunjang Perekonomian Masyarakat?

\section{PEMBAHASAN}

\section{Implementasi Gadai Syariah (Rahn) Di Indonesia}

Pengertian Gadai Syariah (ar-Rahn) Secara etimologi, kata ar-Rahn berarti tetap, kekal, dan jaminan. Akad ar-Rahn dalam istilah hukum positif disebut dengan barang jaminan, agunan dan rungguhan. Dalam Islam ar-Rahn merupakan sarana saling tolong menolong (ta'awun) bagi umat Islam dengan tanpa adanya imbalan jasa. ${ }^{4}$ Sedangkan secara terminologi, ar-Rahn adalah menahan salah satu harta milik si peminjam sebagai jaminan atas pinjaman yang diterimanya, dan barang tersebut memiliki nilai ekonomis. Dengan demikian, pihak yang menahan memperolah jaminan untuk dapat mengambil kembali seluruh atau sebagian piutangnya. ${ }^{5}$

Jadi, ar-Rahn adalah semacam jaminan utang atau lebih dikenal dengan istilah gadai. Berdasarkan hukum Islam, penggadaian merupakan suatu tanggungan atas utang yang dilakukan apabila pengutang gagal menunaikan kewajibannya dan semua barang yang pantas sebagai barang dagangan dapat dijadikan jaminan. Barang jaminan itu baru boleh dijual/dihargai apabila dalam waktu yang disetujui kedua belah pihak, utang tidak dapat dilunasi oleh pihak yang berutang. Oleh sebab itu, hak pemberi piutang hanya terkait dengan barang jaminan, apabila orang yang berutang tidak mampu melunasi utangnya. ${ }^{6}$ Maka orang yang pegang gadai didahulukan dari kreditor-kreditor lain.

Seiring dengan perkembangan zaman dan maraknya lembaga keuangan praktik gadai yang sesuai dengan syariah mulai dilakukan. Praktik gadai syariah atau yang disebut rahn ini sangat menekankan tidak adanya pengenaan riba atau pungutan bunga atas pinjaman yang diberikan. Praktik ini dimulai pertama kali berdasarkan atas perjanjian musyarakah dengan sistem bagi hasil antara Perum Pegadaian dengan Bank Muamalat Indonesia (BMI) dengan tujuan untuk melayani nasabah BMI maupun nasabah Perum Pegadaian yang sesuai dengan prinsip syariah. ${ }^{7}$ Kerjasama ini tertuang dalam perjanjian musyarakah antara BMI dengan Perum Pegadaian Nomor 446 /SP

\footnotetext{
${ }^{3}$ Ibid, hlm. 94.

${ }^{4}$ Nasrun Haroen, Fiqh Mu'amalah, Jakarta: Gaya Media Pratama, 2000, cet. ke-1, hlm. 251

${ }^{5}$ Muhammad Syafi'i Antonio, Bank Syariah: Dari Teori ke Praktik, Jakarta: Gema Insani Press, 2001, cet. ke-1, hlm. 128.

${ }^{6}$ Op.cit,. hlm. 252.

${ }^{7}$ Naida Nur Alfisyahri Dan Dodik Siswantoro, "Praktik Dan Karakteristik Gadai Syariah Di Indonesia", Praktik Dan Karakteristik, Volume 1 | Number 2 July - December 2012, Hal. 119.
} 
300. 233 / 2002 dan Nomor 015 / BMI /PKS /XII /2002 pada tanggal 20 Desember 2002. Dalam hal ini BMI sebagai pihak yang memberikan modal (pembiayaan) bagi pendirian pegadaian syariah di seluruh Indonesia sedangkan Perum Pegadaian sebagai pihak yang menjalankan secara operasional kegiatan usaha pegadaian.

Sesuai dengan Fatwa Dewan Syariah Nasional (DSN) No.25/DSN-MUI/III/2002 yang ditetapkan pada tanggal 28 Maret 2002 oleh ketua dan sekretaris DSN tentang Rahn, menentukan bahwa pinjaman dengan menggadaikan barang sebagai barang jaminan hutang dalam bentuk Rahn diperbolehkan dengan ketentuan sebagai berikut :

1. Penerima gadai (Murtahin) mempunyai hak untuk menahan barang jaminan (Marhun bih) sampai semua utang nasabah (Rahin) dilunasi.

2. Barang jaminan (Marhun bih) dan manfaatnya tetap menjadi milik nasabah (Rahin).

3. Pemeliharaan dan penyimpanan barang gadai pada dasarnya menjadi kewajiban nasabah, namun dapat dilakukan juga oleh penerima gadai, sedangkan biaya dan pemeliharaan penyimpanan tetap menjadi kewajiban nasabah.

4. Besar biaya pemeliharaan dan penyimpanan barang gadai tidak boleh ditentukan berdasarkan jumlah pinjaman.

5. Penjualan barang gadai.

6. Jika terjadi perselisihan antara kedua belah pihak, maka penyelesaiannya dapat dilakukan melalui Badan Arbitrase Nasional, setelah tercapai kesepakatan musyawarah.

Fatwa Dewan Syariah Nasional Nomor: 26/DSN-MUI/III/2002 yang ditetapkan pada tanggal 28 Maret $2002 \mathrm{M}$, tentang Rahn Emas Memutuskan bahwa :

1. Rahn Emas dibolehkan berdasarkan prinsip rahn (lihat Fatwa DSN Nomor: 25/DSNMUI/III/2002 tentang Rahn).

2. Ongkos dan biaya penyimpanan barang (Marhun) ditanggung oleh penggadai (rahin).

3. Ongkos sebagaimana dimaksud ayat 2 besarnya didasarkan pada pengeluaran yang nyatanyata diperlukan.

4. Biaya penyimpanan barang (marhun) dilakukan berdasarkan akad ijarah.

Syarat Sah dan Rukun Gadai Syariah, sebelum dilakukan rahn, terlebih dahulu dilakukan akad. Akad menurut Mustafa az-Zarqa' adalah ikatan secara hukum yang dilakukan oleh 2 pihak atau beberapa pihak yang berkeinginan untuk mengikatkan diri. Kehendak pihak yang mengikatkan diri itu sifatnya tersembunyi dalam hati. Karena itu, untuk menyatakan keinginan masing-masing diungkapkan dalam suatu akad. Ulama fiqh berbeda pendapat dalam menetapkan rukun rahn. Menurut jumhur ulama, rukun rahn itu ada 4 (empat), yaitu:

1. Shigat (lafadz ijab dan qabul).

2. Orang yang berakad (rahin dan murtahin). 
3. Harta yang dijadikan marhun.,dan

4. Utang (marhun bih).

Hak dan Kewajiban Para Pihak Gadai Syariah ${ }^{8}$ Menurut Abdul Aziz Dahlan, bahwa pihak rahin dan murtahin, mempunyai hak dan kewajiban yang harus dipenuhi. Sedangkan hak dan kewajibannya adalah sebagai berikut: ${ }^{9}$

1. Hak dan Kewajiban Murtahin

a. Hak Pemegang Gadai;

1) Pemegang gadai berhak menjual marhun, apabila rahin pada saat jatuh tempo tidak dapat memenuhi kewajibannya sebagai orang yang berutang.Sedangkan hasil penjualan marhun tersebut diambil sebagian untuk melunasi marhun bih dan sisanya dikembalikan kepada rahin.

2) Pemegang gadai berhak mendapatkan penggantian biaya yang telah dikeluarkan untuk menjaga keselamatan marhun.

3) Selama marhun bih belum dilunasi, maka murtahin berhak untuk menahan marhun yang diserahkan oleh pemberi gadai (hak retentie).

b. Kewajiban Pemegang Gadai:

1) Pemegang gadai berkewajiban bertanggung jawab atas hilangnya atau merosotnya harga marhun, apabila hal itu atas kelalaiannya.

2) Pemegang gadai tidak dibolehkan menggunakan marhun untuk kepentingan sendiri.

3) Pemegang gadai berkewajiban untuk memberi tahu kepada rahin sebelum diadakan pelelangan marhun.

c. Hak dan Kewajiban Pemberi Gadai Syariah. Hak Pemberi Gadai:

1) Pemberi gadai berhak untuk mendapatkan kembali marhun,setelah pemberi gadai melunasi marhun bih.

2) Pemberi gadai berhak menuntut ganti kerugian dari kerusakan dan hilangnya marhun, apabila hal itu disebabkan oleh kelalaian murtahin.

3) Pemberi gadai berhak mendapatkan sisa dari penjualan marhun setelah dikurangi biaya pelunasan marhun bih, dan biaya lainnya.

4) Pemberi gadai berhak meminta kembali marhun apabila murtahin telah jelas menyalahgunakan marhun.

d. Kewajiban Pemberi Gadai:

1) Pemberi gadai berkewajiban untuk melunasi marhun bih yang telah diterimanya dari murtahin dalam tenggang waktu yang telah ditentukan, termasuk biaya yang lain yang telah ditentukan murtahin.

2) Pemberi gadai berkewajiban merelakan penjualan atas marhun miliknya, apabila dalam jangka waktu yang telah ditentukan rahin tidak dapat melunasi marhun bih kepada murtahin.

\footnotetext{
${ }^{8}$ Abdul Aziz Dahlan, Ensiklopedi Hukum Islam, Jakarta: Ichtiar Baru Van Hoeve, 2000. hlm. 10.

${ }^{9}$ Ibid,. hal 10-15.
} 
Apabila di tinjau dari ketentuan yang telah diuraikan diatas bahwa pengaturan dan ketentuan-ketentuan tentang gadai syariah (rahn) sudah sangat jelas, untuk mengatur masyarakat, dalam pelaksanaannya juga dimasyarakat gadai syariah telah mengikuti ketentuan tersebut. Banyak masyarakat yang mengadaikan barangnya berupa emas yang untuk digunakan sebagai modal usaha dalam berinvestasi. ${ }^{10}$

Berikut beberapa bisnis syariah yang dijalankan oleh PT Pegadaian (persero): ${ }^{11}$

1. Pegadaian Rahn, pemberian pinjaman dengan perikatan Gadai yang berlandaskan pada prinsipprinsip syariah. Alur dan proses layanan yang diberikan sama dengan Pegadaian KCA, namun nasabah tidak dikenakan sewa modal, melainkan dikenakan ujrah yang dihitung dari taksiran barang jaminan yang diserahkan. Besaran ujrah yang dihitung dari taksiran barang jaminan yang diserahkan. Besaran tarif ujrah maksimal adalah $0,71 \%$ (dari taksiran barang jaminan) per 10 hari dengan jangka waktu maksimum 4 (empat) bulan, tetapi dapat diperpanjang dengan cara mengangsur ataupun mengulang gadai, serta dapat dilunasi sewaktu-waktu dengan perhitungan ujrah secara proporsional selama masa pinjaman

2. Pegadaian Arrum (Ar Rahn untuk Usaha Mikro/Kecil), Layanan pembiayaan dengan skim syariah, baik yang diperuntukkan bagi pengusaha mikro dan kecil guna pengembangan usaha dengan jaminan BPKB kendaraan bermotor, maupun bagi masyarakat yang belum/tidak mempunyai usaha dengan jaminan emas. Pengembalian pembiayaan dilakukan secara angsuran dengan jangka waktu mulai dari 12 bulan hingga 36 bulan yang dapat dilunasi sewaktu-waktu.

3. Pegadaian Amanah,

Pemberian pinjaman atau kredit untuk kepemilikan kendaraan bermotor kepada para karyawan tetap pada suatu instansi atau perusahaan tertentu atau bagi para pengusaha mikro kecil. Dasar pemberian pinjaman dengan menghitung repayment capacity yang ditentukan atas dasar besarnya penghasilan/ gaji bagi karyawan tetap atau berdasar kelayakan usaha bagi pengusaha mikro kecil. Pola perikatan jaminan dilakukan dengan akad rahn tasjily, yang mekanismenya mirip dengan Fidusia.

\section{Keuntungan Gadai Syariah (Ranh) dibandingkan dengan Lembaga pembiayaan lain Untuk Menunjang Perekonomian Masyarakat}

Dengan seiring perkembangan dan kebutuhan masyarakat untuk memenuhi kebutuhannya yang bersifat komsumtif maupun sebagai penunjang perekonemian

\footnotetext{
${ }^{10}$ Lastuti Abubakar, "Pranata Gadai sebagai Alternatif Pembiayaan Berbasis Kekuatan Sendiri", Mimbar Hukum Volume 24, Nomor 1 Febuari 2012, hlm. 6.

${ }^{11}$ Lastuti Abubakar dan Tri Handayani, "Telaah Yuridis Perkembangan Regulasi Dan Usaha Pergadaian Sebagai Pranata Jaminan Kebendaan”, Jurnal Bina Mulia Hukum Volume 2, Nomor 1, September 2017, hlm. 83 .
} 
masyarakat. Masyarakat banyak membutuhkan pembiayaan baik secara Konvensional maupun secara Syariah. Disini penulis akan menganalisis keuntungan Gadai Syariah (Rahn) dibandingkan Lembaga Pembiayaan Lain.

Menurut Akram Khan: ${ }^{12}$ menyatakan bahwa gadai syariah sebagai konsep utang piutang yang sesuai dengan syariah, karena bentuknya yang lebih tepat adalah skim qardhul hasan disebabkan kegunaannya untuk keperluan yang sifatnya sosial. Dijabarkan bahwa pinjaman tersebut diberikan gadai syariah untuk tujuan kesejatraan, seperti pendidikan, kesehatan dan kebutuhan darurat lainnya, terutama diberikan untuk kepentingan membantu meringankan beban ekonomi para orang yang berhak menerima zakat (Mustahiq). ${ }^{13}$ maka dapat disimpulkan bahwa dalam bentuk Skim quarhul hasan ini. Utang yang yang telah disepakati diwajibkan dilunasi pada waktu jatuh tempo tanpa adanya tambahan bunga. Peminjam hanya membayarkan atau menaggung biaya yang secara nyata merupakan kewajiban yaitu biaya administrasi, biaya penyimpanan yang semuanya itu dibayaran dalam bentuk uang, bukan presentase atau bunga.

Keuntungan gadai syariah apabila dibandingkan dengan lembaga lainnya:

1. Waktu yang relatif singkat untuk memperoleh uang pinjaman, yaitu pada hari itu peminjam datang ke pengadaian pada hari itu juga uang yang dibutuhkan cair, ini karena pengadaian prosedurnya yang sederhana

2. Bila dilihat dari persyaratanya pun sangat sederhana, sehingga masyarakat untuk menunjang perekonomian.

3. Apabila dilihat dari pengadaian konvesional tidak ada kewajiban masyarakat memberi tahu kepada pihak pengadaiannya uang yang diberian untuk keperluan apa, tetapi dalam pengadaian syariah pengunaan dana yang akan digunakan lebih baik di beritahukan agar pihak pengadaian mengetahui jenis akad apa yang lebih tepat untuk masyarakat tesebut.

Selain itu Apabila ditinjau dari sifat akadnya gadai syariah (rahn) memiliki 2 bagian yaitu untuk keperluan konsumtif (akad qardhul hasan dan ijarah) dan keperluan modal usaha yang sifatnya produktif yang dari usaha itu nasabah dapat menghasilkan keuntungan maupun menghasilkan kerugian (akad mudharabah, musyarakah, ba'i mquyyadah dan rahn). Dalam akad untuk keperluan modal usaha ada ketentuan bahwa selama rahim memberi izin kepada murtahin bahwa dia boleh memanfaatkan barang yang digadakan tesebut maka barang tersebut dapat digunakan dan keuntungannya wajib di bagikan kepada rahin sesuai dengan bagian kesepakatan yang telah dibuat, selain itu juga rahin dapat memanfaatkan mahrum untuk kepentingan usaha dengan syarat telah mendapatkan izin dari murtahin, apabila dalam pemanfaat mahrum itu menghasilkan keuntungan wajib dibagikan kepada murtahin sesuai dengan kesepakatan bagi hasil yang telah dipersyaratkan karena mahrum berada di bawah penguasaan murtahin.

\footnotetext{
${ }^{12}$ Adrian Sutedi, Hukum Gadai Syariah, Bandung : ALFABETA, 2011, hlm. 71.

${ }^{13} \mathrm{Ibid}$, . hlm. 71.
} 
Dalam gadai syariah juga memiliki keuntungan lain apabila nasabah memilih akad mudharabah dalam mengadaiakan objek gadainya untuk kepentingan modal usaha contonya membuka tempat photo copyan, setelah dilakukan perhitungan yang matang oleh murtahin dapat memberikan pinjaman kepada rahin. Keuntungan dari hasil photo copyan setelah dikurangi dengan biaya yang nyata maka dilakukan bagi hasil keuntungan menurut kesepakatan awal dan kepakatan bagi hasil tersebut akan berakhir pada saat keuntungan bagi hasil tersebut telah melunasi modal yang dipinjamkan, dan apabila dalam kegiatan usaha photo copyan itu mengalami kerugian, kerugian tersebut akan ditanggung bersama.

Dari paparan tersebut jelas bahwa dengan menggunakan gadai syariah masyarakat yang ingin memunjang perekonomian dengan cara melakukan usaha menguntungkan karena dalam gadai syariah prinsip utamanya untuk sosial yaitu membantu masyarakat untuk ketingkat yang lebih maju selain itu juga dalam pengadaian syariah menitik beratkan pada ketentuan hukum islam berdasaran fatwa dan atau peryataan kesesuaian syariah dengan DSN-MUI yang menyatakan bahwa harus memenuhi prinsip keadilan (adl). keseimbangan (tawazun), kemaslahatan (maslahah), universalisme (alamiah), tidak mengandung gharar (objek tidak jelas), mysir (spekulatif), riba (penamabahan pendapatan secara tidak sah), zhulm (ketidakadilan bagi pihak lain), risywah (tindakan suap) dan objek haram. ${ }^{14}$

\section{KESIMPULAN}

Implementasi gadai syariah diindonesia telah sangat berkembang Seiring dengan perkembangan zaman dan maraknya lembaga keuangan praktik gadai yang sesuai dengan syariah mulai dilakukan. Praktik gadai syariah atau yang disebut rahn ini sangat menekankan tidak adanya pengenaan riba atau pungutan bunga atas pinjaman yang diberikan. Praktik ini dimulai pertama kali berdasarkan atas perjanjian musyarakah dengan sistem bagi hasil antara Perum Pegadaian dengan Bank Muamalat Indonesia (BMI) dengan tujuan untuk melayani nasabah BMI maupun nasabah Perum Pegadaian yang sesuai dengan prinsip syariah. Selain itu pengadaian syariah sangat memberikan maanfaat terhadap masyarakat, dilihat dari keuntungan - keuntungannya, gadai syariah merupakan solusi untuk masyarakat dalam membantu peningkatan perekonomian ini tergambarkan berdasarkan ketentuan awal bahwa gadai syariah tersebut untuk kepentingan sosial, yang pada intinya bahwa dalam pelaksanaan gadai tersebut untuk membantu masyarakat.

\section{DAFTAR PUSTAKA}

\section{Buku}

Abdul Aziz Dahlan, Ensiklopedi Hukum Islam, Jakarta: Ichtiar Baru Van Hoeve, 2000. Adrian Sutedi, Hukum Gadai Syariah, Bandung: ALFABETA, 2011.

\footnotetext{
${ }^{14}$ Lastuti Abubakar dan Tri Handayani, Telaah Yuridis Perkembangan Regulasi dan Usaha Pergadaian Sebagai Pranata Jaminan Kebendaan Jurnal Bina Mulia Hukum Volume 2, Nomor 1, September 2017, hlm. 83 .
} 
Dialogia luridica: Jurnal Hukum Bisnis dan Investasi

Volume 10 Nomor 2, April 2019

Muhammad Syafi'i Antonio, Bank Syariah: Dari Teori ke Praktik, Jakarta: Gema Insani Press, 2001), cet. ke-1.

Nasrun Haroen, Fiqh Mu'amalah, Jakarta: Gaya Media Pratama, 2000, cet. ke-1.

\section{Jurnal}

Lastuti Abubakar, "Pranata Gadai Sebagai Alternatif Pembiayaan Berbasis Kekuatan Sendiri”, Mimbar Hukum, Volume 24, Nomor 1 Febuari 2012

Lastuti Abubakar dan Tri Handayani, "Telaah Yuridis Perkembangan Regulasi dan Usaha Pergadaian Sebagai Pranata Jaminan Kebendaan” Jurnal Bina Mulia Hukum, Volume 2, Nomor 1, September 2017.

Naida Nur Alfisyahri dan Dodik Siswantoro, "Praktik dan Karakteristik Gadai Syariah Di Indonesia", Praktik dan Karakteristik, Volume 1 | Number 2 July - December 2012.

Prihantono, "Peran Bank Dan Pegadaian Syariah Dalam Pemenuhan Kebutuhan Ekonomi Rumah Tangga”, Jurnal Khatulistiwa - Journal Of Islamic Studies, Volume 4 Nomor 1 Maret 2014.

Rachmad Saleh Nasution, "Sistem Operasional Pegadaian Syariah Berdasarkan Surah Al-Baqarah 283 pada PT. Pegadaian (Persero) Cabang Syariah Gunung Sari Balikpapan”, Al-Tijary Jurnal Ekonomi dan Bisnis Islam, 2016, Vol. 1, No. 2, hal. 94. 